\title{
Selected Aspects of Corporate Social Responsibility in the Industry Related to the Production and Supply of Energy
}

\author{
Mateusz Kurowski * (D) and Katarzyna Huk \\ Department of Logistics and Information Systems, Faculty of Economics and Management, \\ University of Zielona Góra, ul. Podgórna 50, 65-001 Zielona Góra, Poland; k.huk@wez.uz.zgora.pl \\ * Correspondence: m.kurowski@wez.uz.zgora.pl
}

Citation: Kurowski, M.; Huk, K. Selected Aspects of Corporate Social Responsibility in the Industry Related to the Production and Supply of Energy. Energies 2021, 14, 7965. https://doi.org/10.3390/en14237965

Academic Editor: Donato Morea

Received: 1 November 2021

Accepted: 26 November 2021

Published: 29 November 2021

Publisher's Note: MDPI stays neutral with regard to jurisdictional claims in published maps and institutional affiliations.

Copyright: (c) 2021 by the authors. Licensee MDPI, Basel, Switzerland. This article is an open access article distributed under the terms and conditions of the Creative Commons Attribution (CC BY) license (https:/ / creativecommons.org/licenses/by/ $4.0 /)$.

\begin{abstract}
The development of the economy is related not only to its benefits, but also its negative aspects. One of the negative impacts is the impact on the environment and society. Many types of industry and, in a narrower sense, of enterprises, adversely affect their surroundings. It is one of the many factors that has contributed to the growing popularity of the concept of corporate social responsibility (CSR). It is important to balance business and industry with the environment and community impacts. This study presents selected aspects of corporate social responsibility, such as society, the environment, and corporate governance in relation to the industry responsible for energy production and distribution. This group includes the energy sector (mining oil, gas, consumer fuels, and energy equipment and services), the materials sector (metallurgy and mining), as well as distribution (gas, electricity supply, independent energy producers, and renewable energy). The aim of the article was to present the level of implementation of the concept of corporate social responsibility in enterprises responsible for the production and supply of energy. The article uses the analysis of the literature and the statistical analysis showing the level of use of the described concept in the analysed entities. It was based on an analysis of 1904 companies from 41 countries around the world. The article presents the level of implementation of the concept of corporate social responsibility in selected sectors, divided into three areas: social, environmental, and corporate governance. In each of them, the analysis was performed with regard to the selected, most important factors. In addition, an analysis of the described industry, in relation to the others, is presented, which shows the level of use of individual CSR aspects. Thus, it shows which criteria are followed by enterprises in their activities and indicates the real areas of CSR impact on companies.
\end{abstract}

Keywords: CSR; environmental impact; social impact; corporate governance; energy industry; mining industry

\section{Introduction}

Changes taking place in the economy generate a negative impact for the entire world. The development of industry in many cases is associated with environmental degradation and a negative impact on the local society. The answer to these actions is the concept of Corporate Social Responsibility (CSR). It implements the goals of sustainable development, while focusing on selected aspects related to the environment, the way the organization is managed, the approach to employees, and the local community. This concept is the subject of this article. Its main direction was focused on the analysis of corporate social responsibility in sectors of the economy which, on one hand, are crucial for us, and, on the other hand, generate a negative impact on our environment. The sectors selected for the analysis were divided into three main groups: the energy sector (oil, gas, consumer fuels, and energy equipment and services), the materials sector (metallurgy and mines), and distribution (gas, electricity, and independent energy producers and renewable energy). The aim of the article was to present the level of implementation of the concept of CSR in enterprises responsible for the production and supply of energy. The article also sets research questions, the answers of which are included in the empirical part of the study: 
(1) Which factors, in terms of environmental, social, and corporate governance aspects, affect the level of CSR implementation?

(2) Does the level of implementation of CSR concepts in the energy industry differ from other sectors?

(3) Which is the biggest problem in the field of CSR in the energy industry?

(4) What factors affect the level of implementation of the CSR concept in the energy industry?

The article uses an analysis of the literature and a statistical analysis of CSR grades. The analysis was carried out on 1904 companies from 41 countries around the world. The analysis of the level of use of the concept of CSR in the surveyed entities was mainly carried out, broken down into selected sectors. The article adopted three areas: social, environmental, and corporate governance, which in a broader sense indicated the approach of companies to the assumptions of this concept.

\section{Corporate Social Responsibility-Idea and Application Possibilities}

The main goal of enterprises is to meet the needs of their customers. We can translate the following statement directly to the goals of given sectors, branches of the economy. Their main activity is meeting the needs of citizens. The extraction of basic natural resources is necessary to meet human physiological needs. There are goods such as gas, energy, and water, without which man is unable to exist, let alone live at the present level, taking advantage of technological progress. Unfortunately, industry also generates negative environmental and social impacts. To maintain a balance between development and our natural environment, the idea of sustainable development emerged. The main goal of sustainable development is to meet the needs of the present without compromising the abilities of future generations [1]. Sustainable development is based on social, economic, and environmental integration, through environmental protection, the involvement of each generation, taking care of development and quality of life, and searching for alternative forms of development [2-5]. According to the definition developed by the United Nations, corporate social responsibility is the overall contribution of enterprises to sustainable development [6]. Additionally, it should be noted that sustainable development is the obligation of each entity to conduct business in a transparent and ethical manner [7].

One of the concepts most closely related to sustainable development is corporate social responsibility (CSR). It is a non-profit-maximizing activity that takes into account various social groups that are not the company's shareholders [8]. As defined by Y.CH. Kang and D.J. Wood, "social responsibility means the obligation of each organization to adhere to moral and social standards at every stage of its activity" [9]. It is also a way of solving problems caused by the activity of a given entity, a set of obligations of an organization to protect and strengthen society [10], contributing to the protection and multiplication of social welfare, while maintaining their voluntary approach to the implemented activities towards the environment and society [11]. According to A.B. Caroll, corporate social responsibility consists of various types of responses, to a different extent related to social requirements [12]. In the literature, we find the division of corporate social responsibility into the following areas: economic, environmental, social, and ethical [13-15]. A.B. Carroll first pointed to the economic, legal, ethical, and discretionary expectations of society towards the organization [16]. A few years later, the same author revised the four aspects of the CSR pyramid as economic, legal, ethical, and philanthropic [17]. According to Drucker, the idea lies precisely in ensuring the economic benefit of the enterprise, where, after ensuring its basic activity, it is only possible to invest in the competences of employees in order to achieve wealth [18]. It should be emphasized that enterprises are not only the subject of rights and obligations, but also of economic, legal, and social responsibility [19]. In a broader sense, corporate social responsibility also means following the principles of open competition [8], caring for the development and rights of employees [20,21], the natural environment [22], social dialogue, transparent relations and searching for solutions suitable for all [23], their quality of life, and the welfare of society [24-28], taking 
into account the needs of stakeholders of a given organization [29]. Thus, the idea of this concept applies to broad goals, as well as those in a narrow sense, limited to given enterprises and individuals [30].

When referring to the industry of energy and mining, energy utilities, there are many studies on this sector in the context of sustainable development. Most of the items devoted to this subject refer to the creation of alternative energy sources as a solution and response to sustainable development [31-39]. However, there are few studies and research on the implementation and functioning of corporate social responsibility in these sectors. It is true that the literature indicates the essence of reporting [40] and corporate governance [41]. The research gap is, however, the level of using the concept of corporate social responsibility in these sectors. It is a fairly sensitive area of the economy that society needs as basic goods (water, energy) and is also an exhausting good. Hence, it is a major focus of sustainable development. It would therefore seem that the area of CSR should also be a model area for other sectors of the economy. However, there are no studies and reports on this subject, hence it has been taken up in this study.

The ECOTEC study (2007) provides guidelines and recommendations for CSR in the electricity and gas markets. They mainly concern the restructuring of the energy economy, which involves the transition to renewable energy sources, and thus the retraining of employees and structural changes. In addition, the need to promote new solutions and prepare national plans for social action is indicated [42]. Similarly, OLADE (Quito, Ecuador) (2014) points to the need for education in the implementation of CSR in these sectors, by focusing on the role of CSR promoters in given countries and regions [43]. The Uusimaa Regional Council (Helsinki, Finland) in cooperation with the countries of the Baltic Sea region (2007) and Wilde-Ramsing (2009) highlight the critical issues that should form the basis for the development of a comprehensive CSR policy. These issues can be divided into three pillars of sustainable energy development: social issues, environmental issues, and economic issues [44,45]. It is enterprises from the energy sector which are the largest consumers of fossil fuels. Moreover, they emit the most carbon dioxide. The more developed the economy, the greater its negative impact on the environment [46].

CSR is important for the energy sector, which can be seen by adjusting its policy to sustainable development standards and its reporting, such as: Global Reporting Initiative (GRI) (Amsterdam, Netherlands), OECD Guidelines for Multinational Enterprises (Paris, France), UN Global Compact, Carbon Disclosure Project (CDP). According to studies by EPSU et al., as many as $70 \%$ of enterprises from the analysed sector are members of the UN Global Compact, and 38\% refer to the OECD guidelines in their reports and public documents. The CDP standard for $\mathrm{CO}_{2}$ reporting is used by as many as $80 \%$ of companies, and $67 \%$ report CSR according to GRI G3. Furthermore, $63 \%$ of companies applying the GRI guidelines also use the supplement for the electricity sector (EUSS). About $38 \%$ of the surveyed companies use all CSR initiatives, and 13\% do not use any of them. Moreover, the authors of the report conclude that this is not responsible behaviour of these companies, and declarations made may not be reality [44].

Analysing the literature on the subject of CSR research in the mining industry over the years and corporate policies in the field of CSR, it can be concluded that, in 2004, the CSR approach for mining industry did not differ from other sectors. However, there is pressure from the environment and society. In order to avoid conflicts, the first steps are taken to minimize the negative impact on the environment and local society [47]. Subsequent studies have shown that there are large differences in reporting in mining companies. Although reporting improves over time, there is a large gap between supporters and opponents [48]. CSR has become a popular topic in Peru. Recommendations and guidelines for this sector were prepared, but due to the differences between individual enterprises, benchmarking was indicated as recommendations for enterprises [49]. In the following years, ready-made tools appeared, such as an instrument based on 31 indicators, divided into three groups: sustainable development, ethics, and human resources. The idea behind this activity was the systematic analysis of the Global CSR Index [50]. The authors also pay attention to 
different interpretations of CSR and the specificity of a given country. Hence, it seems important to adjust the guidelines for the mining sector [51]. The specificity of the sector, however, seems to be similar, as evidenced by research-a comparative analysis of two mines located in the Czech Republic and Zambia. No definite differences were detected; on the contrary, the mines struggled with the same problems [52]. Therefore, the stakeholders of these sectors should also have an impact in the field of CSR, thanks to which some of their problems could be overcome [53]. Research has shown that one of the stakeholder groups-the state government, is able to strongly influence the CSR policy in the mining industry [54]. Research was also carried out among members of the academic community. They demonstrated the basic knowledge of students in the field of CSR for the energy industry [55]. This is one of the areas that should also undoubtedly be improved, especially in the field of technical universities. The new assumptions for the European Union indicate the main goals in the field of energy, which will also directly affect the implementation of corporate social responsibility, especially in the environmental aspect. The main goals of the common policy are [56]:

- a reduction of at least $40 \%$ in greenhouse gas emissions compared to 1990 levels;

- increasing the share of renewable energy in all consumed energy sources to $32 \%$;

- improvement of energy efficiency by $32.5 \%$;

- interconnections covering at least $15 \%$ of the EU's electricity systems.

The introduced guidelines apply to all sectors described in this article. These changes are crucial for the future and sustainable development. Some of them are also the key assumptions of the concept of corporate social responsibility. Their implementation will undoubtedly contribute to responsible actions taken not only by individual enterprises, but also by the governments of all countries belonging to the European Union community.

The analysis of the literature showed a lack of information on the level of use of particular areas of CSR for sectors related to energy production and distribution. However, they unanimously state that the use of the CSR concept is closer to public relations than to its main idea.

\section{Materials and Methods}

Data for the analysis were obtained from CSR ratings and provided by GES Investment Services. They cover 1904 companies from 41 countries, which were divided into groups based on Global Industry Classification Standard (GICS), as shown in Table 1 [57].

Table 1. Assessed groups of companies.

\begin{tabular}{cc}
\hline Industry & Number of Companies \\
\hline mining & 55 \\
energy & $\mathbf{1 2 9}$ \\
energy utilities & 57 \\
non-energy utilities & 27 \\
consumer discretionary & 296 \\
industrials & 470 \\
consumer staples & 161 \\
health care & 217 \\
IT & 235 \\
communications services & 129 \\
materials without mining & 128 \\
\hline TOTAL & $\mathbf{1 9 0 4}$
\end{tabular}

The subject of this study is determining the level of CSR in environmental, social, and corporate governance areas in 3 groups of companies: mining, energy, and energy utilities (Table 1).

Groups of mining, energy, and energy utilities are the ones that this research is focused on. They represent three different facets of energy activity: 
- mining companies extract fossil fuels for further use.

- the group of energy produces energy and energy utilities distributes energy to end users. From a technical point of view, the energy group is a sector according to GICS.

- energy utilities is a group created for the needs of research by including following industries from GICS utilities sector: gas utilities, electric utilities, independent power, and renewable electricity producers. Other utilities: multi-utilities and water utilities established the group of non-energy utilities. In GICS, mining companies are a part of materials sector. For the needs of this research, they are considered separately.

All companies were assessed on a basis of ESG analysis and covered 9 indicators in each area:

Environment:

- environmental organization and routines;

- environmental policies and targets;

- implementation of environmental management system;

- ISO14001 and/or EMAS certification;

- the quality of environmental data disclosed by the company;

- environmental requirements in supply chain;

- the change in GHG emissions over time;

- the change in emissions of gases other than GHG over time;

- the change in energy use over time.

Social:

- policies and management systems in relation to occupational health and safety;

- activities concerning workplace diversity and discrimination;

- policies on working hours and wages;

- activities to prevent forced labour;

- initiatives in relation to community involvement;

- anti-corruption initiatives;

- policy on human rights in supply chain;

- programs and management systems on human rights in supply chain;

- assessment of human rights in supply chain.

Corporate governance:

- the independence of the board of directors;

- gender parity in the board of directors;

- composition and independence of the nomination committee;

- composition and independence of the audit committee;

- composition and independence of the compensation committee;

- transparency in relation to corporate governance code;

- transparency about CEO's compensation;

- transparency about auditors' compensation;

- providing information on the company's board members.

The score for each indicator was in the range of $[0,3]$. Lack of points meant not taking specific actions in a given scope, or their non-compliance with legal regulations, international agreements, and guidelines of social responsibility. Maximum score meant all requirements concerning specific issues were met. In other cases, obtained score reflected the relation between how a given company performed and what was required in a specific indicator. Points are awarded for: having appropriate routines and organizational solutions, adopting policies and setting specific environmental/social targets, environmental certification and performance, the range and the quality of CSR data disclosed by the company, appointing requirements in relations inside the supply chain, measures, and organizational solutions in the area of corporate governance.

Total environmental, social, and corporate governance grades were calculated as a sum of 9 partial grades obtained in specific areas, therefore they can reach a value in the 
range of $[0,27]$. The sum of total environmental, social, and corporate governance grades is total CSR score which value is between 0 and 81 .

Research is divided into 4 phases. The first 3 phases of research are the comparison of the level of CSR in environmental, social, and corporate governance in following groups: mining, energy, and energy utilities. The last phase is a comparison of CSR level in above-mentioned groups and other sectors of economy.

Statistical methods were used to assess the differences between groups. The ShapiroWilk test was chosen to verify the normality of the distribution of results obtained inside specific groups. Test statistics were calculated according to the formula [58]:

$$
\mathrm{W}=\frac{\left(\sum_{\mathrm{i}=1}^{\mathrm{n}} \mathrm{a}_{\mathrm{i}} \mathrm{X}_{\mathrm{i}}\right)^{2}}{\sum_{\mathrm{i}=1}^{\mathrm{n}}\left(\mathrm{X}_{\mathrm{i}}+\overline{\mathrm{X}}\right)^{2}}
$$

where $a_{i}$-can be found in mathematical tables, $X_{i}-i^{\text {th }}$ order statistic, and $\bar{X}-$ mean.

As not all groups had the distribution close to normal, there were more than two groups to compare, and in regional analysis those groups were not equinumerous, a nonparametric Kruskal-Wallis test was chosen to verify statistical significance of differences. There are related ranks in the sample, so the statistics are counted using the following formula [59]:

$$
\mathrm{H}_{\mathrm{p}}=\frac{\mathrm{H}}{1-\frac{\sum_{\mathrm{i}=1} t_{\mathrm{i}}^{3}-\mathrm{t}_{\mathrm{i}}}{\mathrm{N}^{3}-\mathrm{N}}}
$$

where $\mathrm{N}$ - total number of observations, $\mathrm{t}_{\mathrm{i}}$-the number of observations with the same rank, and $\mathrm{H}$-the result of the Kruskal-Wallis test without applying the corrections for associated ranks [60]:

$$
\mathrm{H}=\frac{12}{\mathrm{~N}(\mathrm{~N}+1)} \sum_{\mathrm{i}=1}^{\mathrm{p}} \frac{\mathrm{R}_{\mathrm{i}}^{2}}{\mathrm{n}_{\mathrm{i}}}-3(\mathrm{~N}+1)
$$

where $\mathrm{p}$-number of compared groups, $\mathrm{R}_{\mathrm{i}}$-sum of ranks in a given group, and $\mathrm{n}_{\mathrm{i}}$ - the number of observations in a given group.

As post hoc analysis Mann-Whitney tests were performed for each pair of assessed groups with the following formula [61]:

$$
\mathrm{U}=\mathrm{R}_{\min (\mathrm{k})}-\frac{\mathrm{n}_{\mathrm{k}}\left(\mathrm{n}_{\mathrm{k}}+1\right)}{2}
$$

where $R_{\min (k)}$ - sum of ranks for the group in which the sum is smaller and $n_{k}$-number of observations in the group with the lower sum of ranks.

Statistics for multiple pairwise comparisons were calculated also in Bonferroni corrected version. The correction of significance level was performed in line with this formula [62]:

$$
\mathrm{PC}_{\alpha}=\frac{\mathrm{EW}_{\alpha}}{\mathrm{k}}
$$

where $\mathrm{PC}_{\alpha}$-Bonferroni corrected significance level, $\mathrm{EW}_{\alpha}$-nominal significance level, and $\mathrm{k}$-number of tests.

\section{Results}

As a result of a conducted literature analysis on the subject of reporting, three main areas were adopted for further analysis of CSR in analysed groups. These are the ESG principles: environmental, social, and corporate governance (Figure 1). 
Social

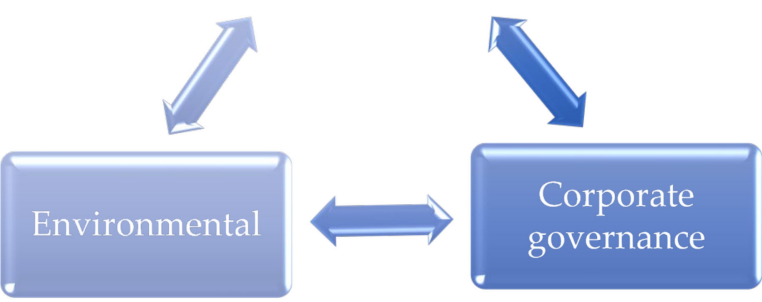

Figure 1. Aspects of corporate social responsibility.

An analysis of the use of the CSR concept in the surveyed companies is carried out below. It was carried out in the following steps:

Step (1): Analysis of CSR-environmental;

Step (2): Analysis of CSR-society;

Step (3): Analysis of CSR - corporate governance;

Step (4): Comparative analysis of selected energy sectors with other sectors.

The distinguished three main areas of CSR will be analysed in individual sub-chapters for three sectors: mining, energy, and energy utilities. In the last chapter, a comparative analysis will be carried out for all sectors identified in the study (mining, energy, energy utilities, non-energy utilities, consumer discretionary, industrials, consumer staples, health care, IT, communications services, and materials without mining). The conducted analysis aims to indicate the level of particular aspects of CSR in enterprises producing and supplying energy, as well as to compare them in the field of all sectors identified in the study.

\subsection{Groups of Mining, Energy, and Energy Utilities in the Area of Environment} Environment

Firstly, the area of environment was assessed. Nine indicators were taken into consideration and the results were shown in Figure 2.

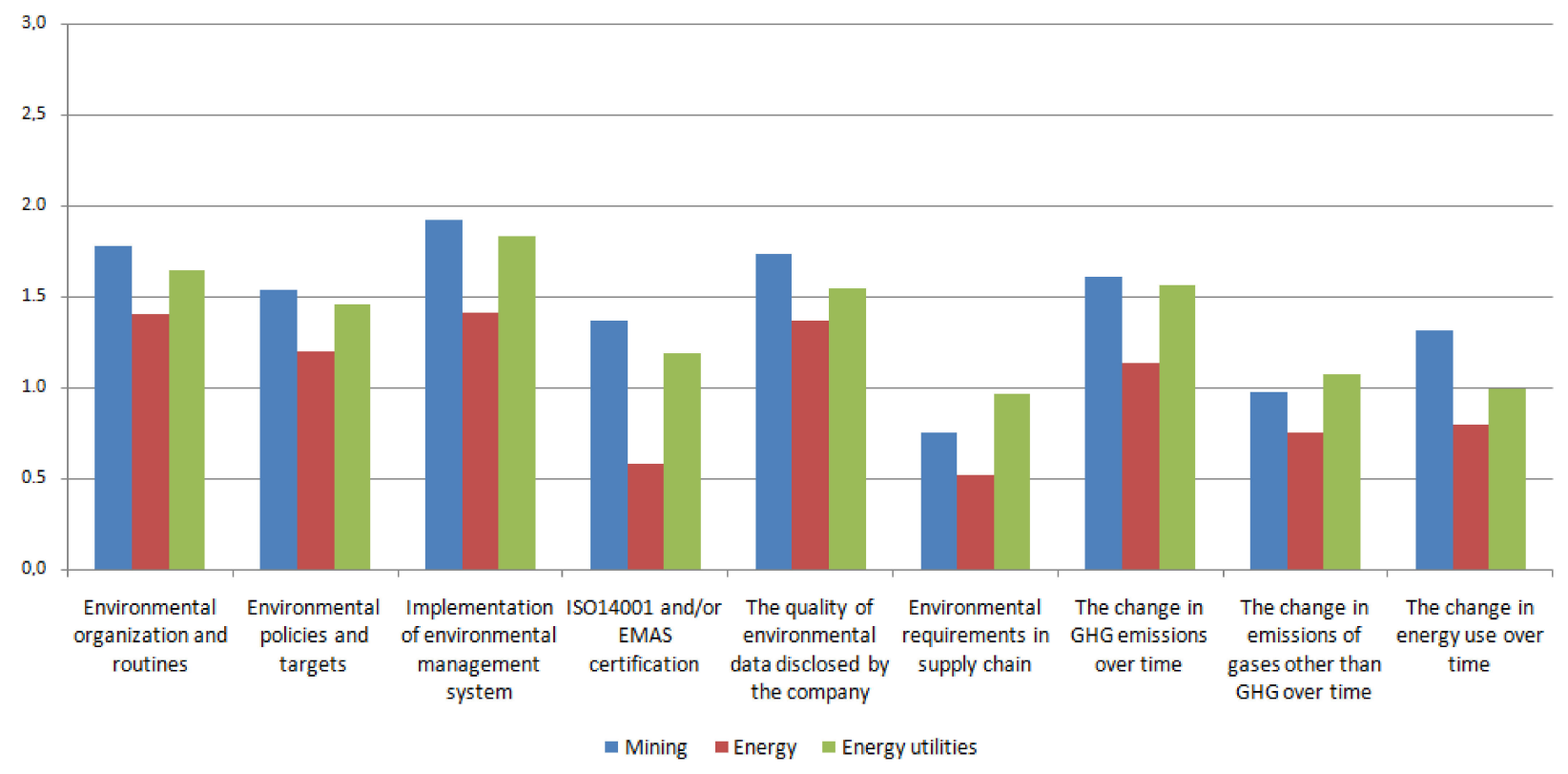

Figure 2. Comparison of mean values of grades obtained in environmental indicators by mining, energy, and energy utilities groups. 
Assessed companies obtained the highest grades in implementation of environmental management system, the quality of environmental data disclosed by the company, and environmental organization and routines.

The group of energy is characterized by the lowest mean values of grades in all nine environmental indicators. Mining companies obtained the highest grades in all indicators except environmental requirements in supply chain and in the change in emissions of gases other than GHG. Mentioned indicators are also the ones where scores were relatively lowest.

Statistical analysis showed that results obtained by companies in the energy group were significantly lower than those in mining and energy utilities (Table 2). There were no statistically significant differences between mining and energy utilities.

Table 2. Statistical significance of differences in total environmental grades, Bonferroni corrected $\backslash$ incorrected.

\begin{tabular}{cccc}
\hline K-W Test: $\boldsymbol{p}=\mathbf{9 . 7 1 7} \times \mathbf{1 0 ^ { - 6 }}$ & Mining & Energy & Energy Utilities \\
\hline Mining & & $2.248 \times 10^{-5 * *}$ & 0.4737 \\
Energy & $6.745 \times 10^{-5 * *}$ & & $0.0006034^{* *}$ \\
Energy utilities & 1 & $0.00181^{* *}$ & \\
\hline${ }^{*} p<0.05,{ }^{* *} p<0.01$. & & &
\end{tabular}

\subsection{Groups of Mining, Energy, and Energy Utilities in the Area of Society Society}

The next area of CSR assessed in the research concerned social issues. Mean values of grades obtained by companies in nine social indicators are presented in Figure 3.

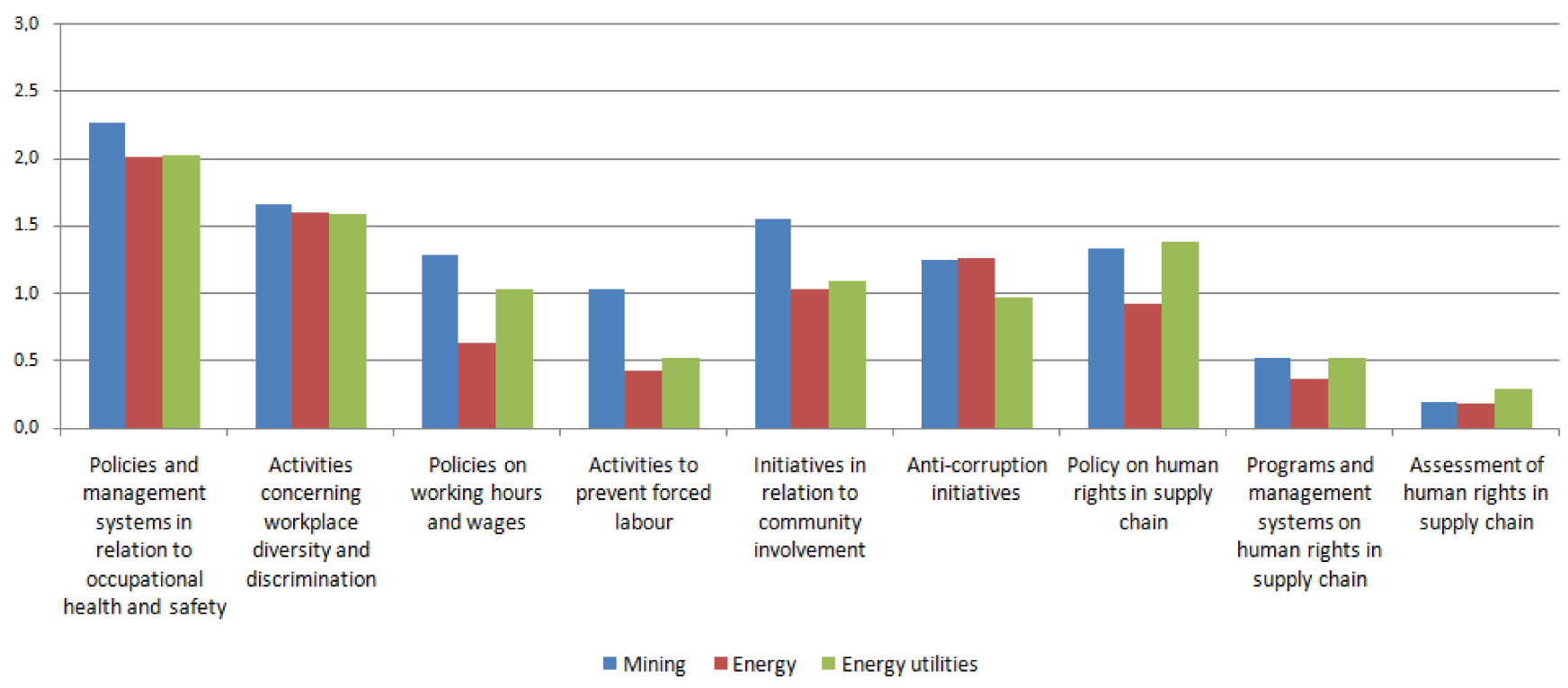

Figure 3. Comparison of mean values of grades obtained in social indicators by mining, energy, and energy utilities groups.

Companies assessed in this phase achieved the highest grades in policies and management systems in relation to occupational health and safety and activities concerning workplace diversity and discrimination. High scores in the first of mentioned indicators are connected with legal regulations and standards set by international organizations and collective agreements. Workplace diversity and discrimination has been one of the most important topics of public debates around the world.

The lowest scores were obtained in indicators concerning supply chain, especially assessment of human rights in supply chain and programs and management systems on human rights in supply chain. 
As in the area of environment, the group of energy is characterized by the lowest mean values of grades. Only in anti-corruption initiatives did it obtain the highest, and in activities concerning workplace diversity and discrimination the second highest, scores. Mining companies were rated highest in six indicators and power utilities in two.

Statistical analysis showed that only the group of mining achieved significantly higher scores than energy (Table 3). Groups of mining and energy did not significantly differ from energy utilities.

Table 3. Statistical significance of differences in total social grades, Bonferroni corrected $\backslash$ incorrected.

\begin{tabular}{cccc}
\hline K-W Test: $\boldsymbol{p}=\mathbf{0 . 0 0 0 5 2 9}$ & Mining & Energy & Energy Utilities \\
\hline Mining & & $9.193 \times 10^{-5 * *}$ & $0.03011^{*}$ \\
Energy & $0.0002758^{* *}$ & & 0.2151 \\
Energy utilities & 0.09033 & 0.6452 & \\
${ }^{*} p<0.05,{ }^{* *} p<0.01$. & &
\end{tabular}

\subsection{Group of Mining, Energy, and Energy Utilities in the Area of Corporate Governance Corporate Governance}

The third part of the analysis was an assessment of nine indicators representing corporate governance area. Mean values obtained by mining, energy, and energy utilities are presented in Figure 4.

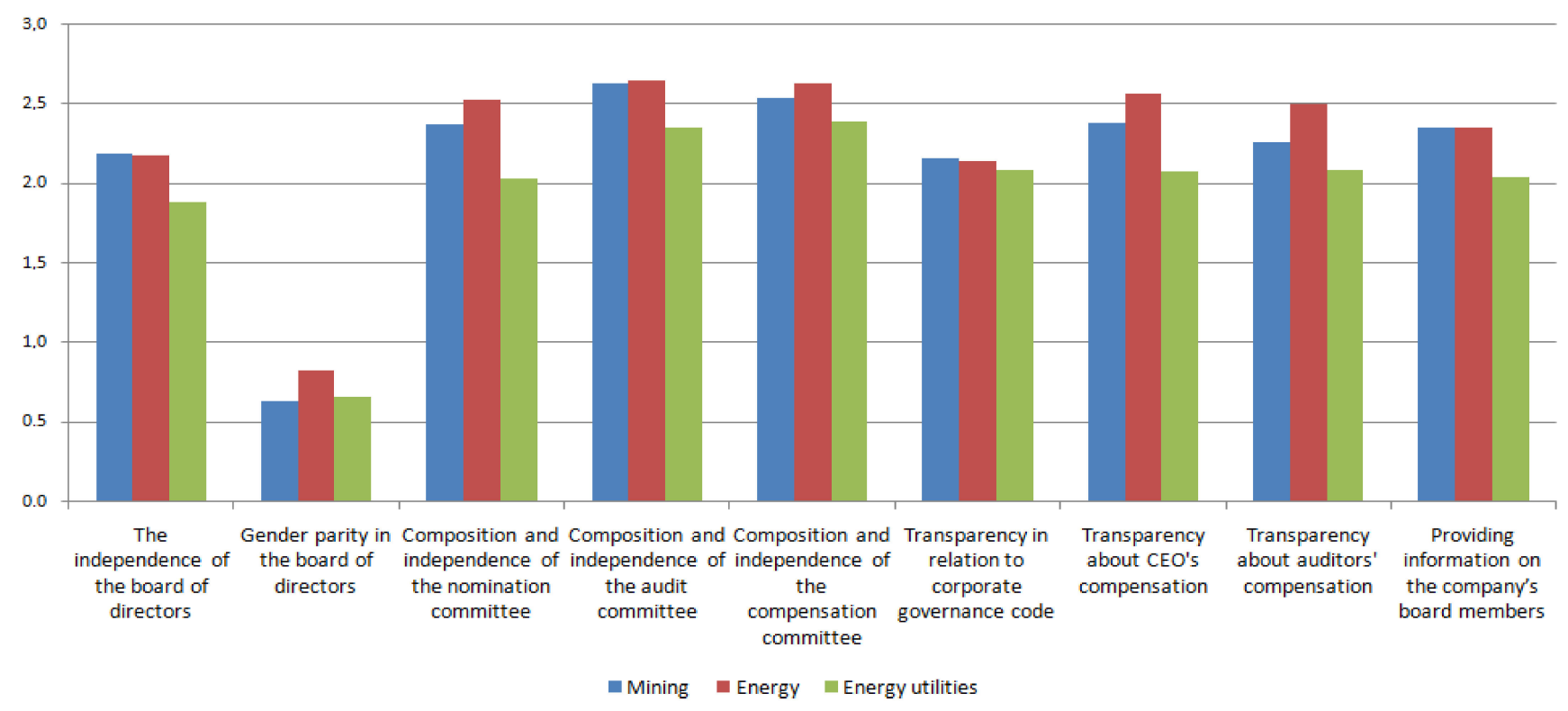

Figure 4. Comparison of mean values of grades obtained in corporate governance indicators by mining, energy, and energy utilities groups.

Mean values of grades obtained in area of corporate governance were significantly higher than in environmental and social aspect. The mean values of total environmental and social scores for companies of all three assessed groups were 10.77 and 9.27, respectively, while for corporate governance it was 19.51 .

Companies obtained comparably high scores in eight corporate governance indicators. There is one negative outlier in the form of gender parity in the board of directors. In this aspect, companies achieved approximately one third of the points they scored in the area of corporate governance, on average.

The group of energy, which was characterized by the lowest mean values of grades of environmental and social indicators, obtained the highest scores in six corporate governance indicators. Mining was the leading group in the remaining three indicators. Companies from energy utilities group scored the lowest in eight indicators. 
Statistical analysis showed that observed differences between groups in terms of corporate governance were not significant (Table 4).

Table 4. Statistical significance of differences in total corporate governance grades, Bonferroni corrected $\backslash$ incorrected.

\begin{tabular}{cccc}
\hline K-W Test: $\boldsymbol{p}=\mathbf{0 . 0 8 1 1 8}$ & Mining & Energy & Energy Utilities \\
\hline Mining & & 0.5622 & $0.03834^{*}$ \\
Energy & 1 & & 0.0591 \\
Energy utilities & 0.115 & 0.1773 & \\
\hline${ }^{*} p<0.05,{ }^{* *} p<0.01$. & & &
\end{tabular}

\subsection{CSR Level in Mining, Energy, and Energy Utilities and Other Sectors of Economy Comparative Analysis with Other Sectors}

Looking for an answer regarding CSR level and related problems and challenges among companies which deal with energy as the main object activity requires not only an internal insight, but also a wider perspective. Some characteristics of CSR performance in mining, energy, and energy utilities may reflect general economic problems, others can be sector-specific.

Average total CSR score for all 1904 companies under research was 37.56, when the mean score for mining was 43.63, energy utilities 39.27, and energy 37.93. It means that all three groups related to energy production and supply represented higher level of CSR then an average company under research. Non-energy utilities can be considered as the most responsible sector with average total CSR grade of 46.21 , and IT as the least responsible at 33.11.

Following the deduction, total environmental, social, and corporate governance grades obtained by specific groups had to be verified. Their mean scores are presented in Figure 5.

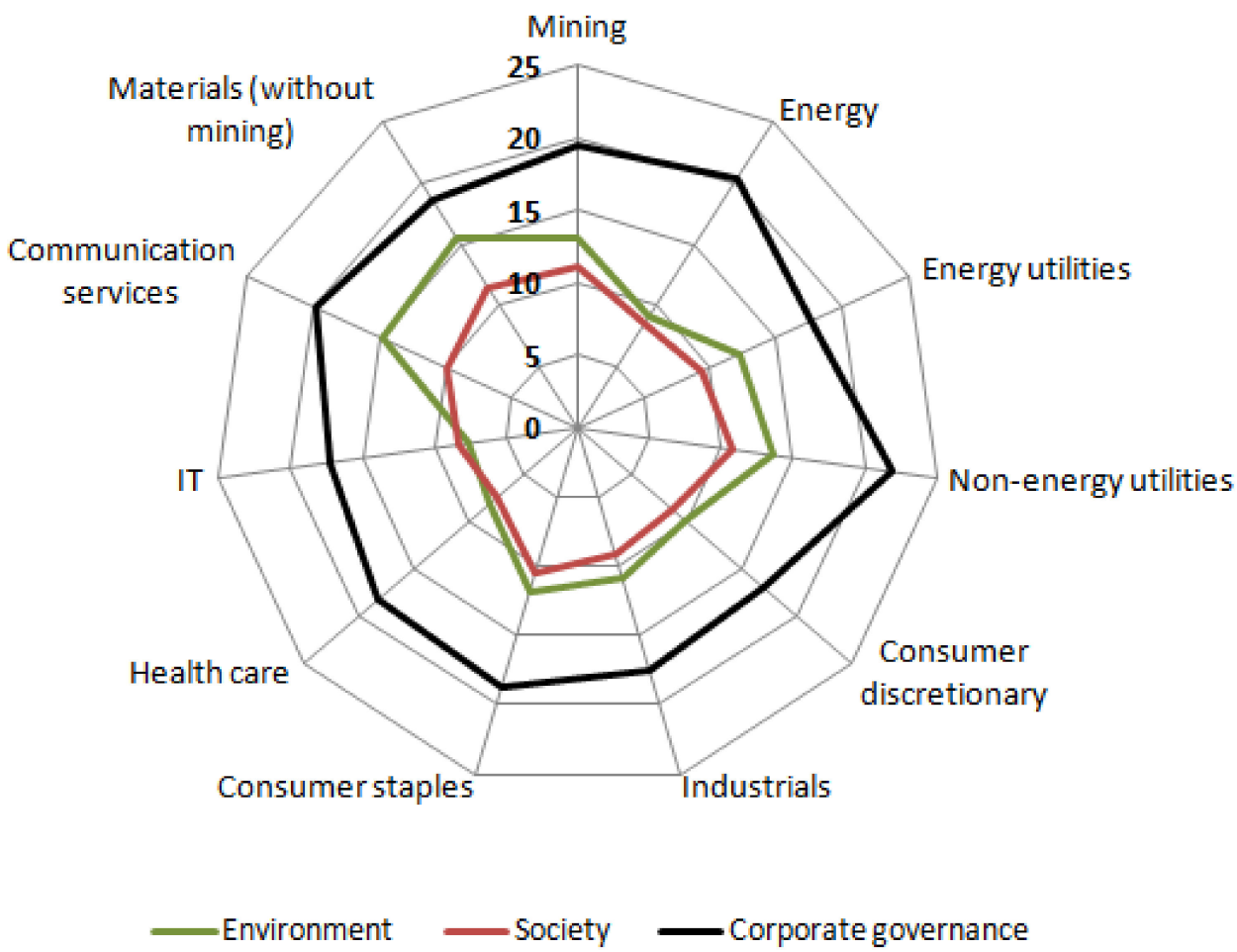

Figure 5. Total environmental, social, and corporate governance grades obtained by groups under research.

All analysed sectors obtained the highest grades in the area of corporate governance and the difference is significant. Differences between total environmental and social scores 
were smaller, and 10 cases mean values of environmental grades were higher than social grades. The opposite situation took place only in the case of IT sector.

In terms of environment materials sector (with mining excluded) obtained the highest grades on average, 15.58, which is more than twice much as it was in IT sector-7.58. Mining and energy utilities are ranked third and fourth in this aspect, while the energy sector performed worse than average.

Additionally, in the social aspect, the materials sector (with mining excluded) appeared to be the highest scoring group with the mean value of 11.49 , while health care scored the lowest grade-7.30. In social aspects, grades were not only lower than in the area of environment, but they were also within narrower spread. The mining group was ranked second, energy utilities sixth, and energy sector ninth.

Mean values of total corporate governance grades were from 16.98 (consumer discretionary) to 21.86 (non-energy utilities). Energy was characterized by second highest score, mining fourth, and energy utilities eighth.

The analysis of individual indicators showed that there were several potential sectorspecific problems in terms of CSR in companies related to energy production and supply. Table 5 presents which environmental indicators companies related to energy production and supply represented higher level of responsibility.

Table 5. Differences in mean values of grades obtained in environmental area by groups of mining, energy, and energy utilities compared to other companies under research.

\begin{tabular}{|c|c|c|c|c|c|c|c|c|c|}
\hline Indicator & $\begin{array}{l}\text { Env. } \\
\text { Organization and } \\
\text { Routines }\end{array}$ & $\begin{array}{l}\text { Env. Policies and } \\
\text { Targets }\end{array}$ & $\begin{array}{l}\text { Impl. of Env. } \\
\text { Management } \\
\text { System }\end{array}$ & $\begin{array}{l}\text { ISO14001 and/or } \\
\text { EMAS Cert. }\end{array}$ & $\begin{array}{l}\text { The Quality of } \\
\text { Env. Data } \\
\text { Disclosed by the } \\
\text { Company }\end{array}$ & $\begin{array}{c}\text { Env. } \\
\text { Requirements in } \\
\text { Supply Chain }\end{array}$ & $\begin{array}{c}\text { The Change in } \\
\text { GHG Emissions } \\
\text { over Time }\end{array}$ & $\begin{array}{l}\text { The Change in } \\
\text { Emissions of } \\
\text { Gases other than } \\
\text { GHG over Time }\end{array}$ & $\begin{array}{c}\text { The Change in } \\
\text { Energy Use over } \\
\text { Time }\end{array}$ \\
\hline difference & $+14.24 \%$ & $+7.00 \%$ & $+14.62 \%$ & $-18.02 \%$ & $+10.95 \%$ & $-22.41 \%$ & $+19.04 \%$ & $+12.07 \%$ & $-0.45 \%$ \\
\hline $\begin{array}{l}\text { Mann- } \\
\text { Whitneytest } p \\
\text { value }\end{array}$ & $0.0001 * *$ & 0.1826 & $0.004104 * *$ & $0.0151^{*}$ & 0.0072 ** & $0.000537 * *$ & $0.00045 * *$ & 0.464 & 0.9736 \\
\hline
\end{tabular}

Companies from groups of mining, energy, and energy utilities obtained higher average grades in six out of nine environmental indicators than the rest of companies under research. Four of these positive differences were statistically significant. The opposite situation concerns three indicators, but the utmost and statistically significant negative difference concerns environmental requirements in supply chain.

Analogical parameters for social area can be found in Table 6 .

Table 6. Differences in mean values of grades obtained in social area by groups of mining, energy, and energy utilities compared to other companies under research.

\begin{tabular}{|c|c|c|c|c|c|c|c|c|c|}
\hline Indicator & $\begin{array}{l}\text { Policies and } \\
\text { mgmt. Systems } \\
\text { in Relation to } \\
\text { Occup. Health } \\
\text { and Safety }\end{array}$ & $\begin{array}{c}\text { Activities } \\
\text { Concerning } \\
\text { Workplace } \\
\text { Diversity and } \\
\text { Discr. }\end{array}$ & $\begin{array}{l}\text { Policies on } \\
\text { Working Hours } \\
\text { and Wages }\end{array}$ & $\begin{array}{l}\text { Activities to } \\
\text { Prevent Forced } \\
\text { Labour }\end{array}$ & $\begin{array}{l}\text { Initiatives in } \\
\text { Relation to } \\
\text { Community } \\
\text { Involv. }\end{array}$ & $\begin{array}{c}\text { Anti- } \\
\text { Corruption } \\
\text { Initiatives }\end{array}$ & $\begin{array}{l}\text { Policy on Human } \\
\text { Rights in Supply } \\
\text { Chain }\end{array}$ & $\begin{array}{l}\text { Programs and } \\
\text { mgmt. Systems } \\
\text { on Human Rights } \\
\text { in Supply Chain }\end{array}$ & $\begin{array}{l}\text { Assessment of } \\
\text { Human Rights in } \\
\text { Supply Chain }\end{array}$ \\
\hline difference & $+32.31 \%$ & $+8.38 \%$ & $-10.25 \%$ & $-31.80 \%$ & $+34.36 \%$ & $+19.40 \%$ & $-21.39 \%$ & $-32.42 \%$ & $-22.96 \%$ \\
\hline $\begin{array}{l}\text { Mann- } \\
\text { Whitneytest } p \\
\text { value }\end{array}$ & $2.87 \times 10^{-15 * *}$ & 0.05616 & 0.03615 * & $2.09 \times 10^{-5 * *}$ & $5.727 \times 10^{-8 * *}$ & $5.001 \times 10^{-6 * *}$ & $0.00016 * *$ & 0.00022 ** & 0.819 \\
\hline
\end{tabular}

Companies from groups of mining, energy and energy utilities obtained significantly higher scores than other companies in three indicators. In two of them, the difference exceeds $30 \%$. The negative difference of similar scale concerns activities to prevent forced labour and programs and management systems on human rights in supply chain.

Differences in area of corporate governance are included in Table 7.

Mining, energy, and energy utilities companies obtained higher grades than other companies in eight indicators, but six of those differences were statistically significant. The opposite situation took place only in gender parity in the board of directors. Differences in area of corporate governance were lower than in two other areas of CSR. 
Table 7. Differences in mean values of grades obtained in area of corporate governance by groups of mining, energy, and energy utilities compared to other companies under research.

\begin{tabular}{|c|c|c|c|c|c|c|c|c|c|}
\hline Indicator & $\begin{array}{l}\text { The Ind. of the } \\
\text { BOD }\end{array}$ & $\begin{array}{c}\text { Gender Parity in } \\
\text { the BOD }\end{array}$ & $\begin{array}{l}\text { Comp. } \\
\text { and Ind. of the } \\
\text { Nomination } \\
\text { Cmte. }\end{array}$ & $\begin{array}{l}\text { Comp. and Ind. } \\
\text { of the Audit } \\
\text { Cmte. }\end{array}$ & $\begin{array}{l}\text { Comp. and Ind. } \\
\text { of the Compens. } \\
\text { Cmte. }\end{array}$ & $\begin{array}{l}\text { Transpar. in } \\
\text { Relation to CG } \\
\text { Code }\end{array}$ & $\begin{array}{c}\text { Transpar. } \\
\text { about CEO's } \\
\text { Compens. }\end{array}$ & $\begin{array}{l}\text { Transpar. about } \\
\text { Auditors' } \\
\text { Compens. }\end{array}$ & $\begin{array}{l}\text { Providing Inf. on } \\
\text { the Company's } \\
\text { Board Members }\end{array}$ \\
\hline difference & $+8.88 \%$ & $-17.69 \%$ & $+11.14 \%$ & $+13.45 \%$ & $+14.60 \%$ & $+3.85 \%$ & $+5.13 \%$ & $+14.88 \%$ & $+8.82 \%$ \\
\hline $\begin{array}{c}\text { Mann- } \\
\text { Whitneytest } p \\
\text { value }\end{array}$ & $0.0084 * *$ & $2.38 \times 10^{-11 * *}$ & $3.108 \times 10^{-6 * *}$ & $1.016 \times 10^{-5 * *}$ & $1.062 \times 10^{-7 * *}$ & 0.3136 & 0.1154 & $4.232 \times 10^{-8 * *}$ & $0.00097^{* *}$ \\
\hline
\end{tabular}

\section{Discussion}

The results of the statistical analysis led to the conclusion that economic and legal incentives exert a significant influence on the implementation of the CSR concept in companies. Corporate governance issues are important for investors and shareholders. Lack of transparency in this respect may directly affect the financial results of the company. Among environmental and social indicators of CSR, there are some which are supported by law regulations in many countries. Relatively high grades in implementation of environmental management systems, the quality of environmental data disclosed by the company, and environmental organization and routines result partially from the pressure on companies dealing with energy production and supply to implement environmental systems and routines. What is more, data collection and disclosure on specific environmental issues is also required by law. This way, following the legal regulations, companies improve their CSR level. It is a subject for further discussion if, in theory, fulfilling legal responsibilities are part of CSR or just a common obligation [12], but in practice there are areas in which these two aspects overlap. The strong influence of government on CSR performance of the companies was also shown in earlier studies [54].

Another point is that companies still do not consider CSR as a collective issue. Research performed in 2017 showed that individual approach is dominating, not only in sectors related to energy [63], and the lowest scores observed in the research were related to CSR in supply chain. What is interesting is the fact that companies deal relatively well with implementing policies on human rights in supply chain. There seems to be a difficulty in turning it into more binding forms of relations with partners in supply chain-programs and management systems. The question also arises what is the base for creating and developing policies, programs, and management systems for companies under research, as they marginalize the problem of human rights in supply chain assessment.

The above observations regarding CSR in the supply chain may also be related to another worrying phenomenon. The problem of forced labour seems to be easy to overcome with modern economy and reliable law systems, but mining, energy, and energy utility companies show low activity in this aspect. There are other studies which confirm that there is a gap in the field of forced labour between CSR standards and business practice [64]. A similar situation applies to policies on working hours and wages. Surprisingly low scores in these indicators can be related to low commitment to supply chain responsibility. Individual approach to CSR often leads to opportunistic use of partners in supply chains, including the pressure on lowering working standards and wages.

Struggling with environmental, social, and corporate governance problems is socially desirable but difficult. There is no single CSR activities template that fits all companies. It is necessary, inter alia, to understand the specifics of a given sector. Research has shown that companies representing groups of mining, energy, and energy utilities did not differ much from each other, nor from other non-energy sectors. Earlier studies on mining companies led to the same observation [47]. Nevertheless, there were some important differences that must be taken into consideration when implementing and developing a company's CSR system. Mentioned above, forced labour can be one of them. This is potentially a problem specific to energy-linked sectors and industries. They also performed worse than other sectors in indicators concerning CSR in supply chain. These are issues where all groups obtained relatively low scores, but in mining, energy, and energy utilities they were even 
significantly lower. These findings are arguments in favour of creating industry-specific CSR guidelines as in, e.g., Peru [49].

Based on above results and observations, the authors propose the CSR model for companies operating as energy producers or suppliers (Figure 6).

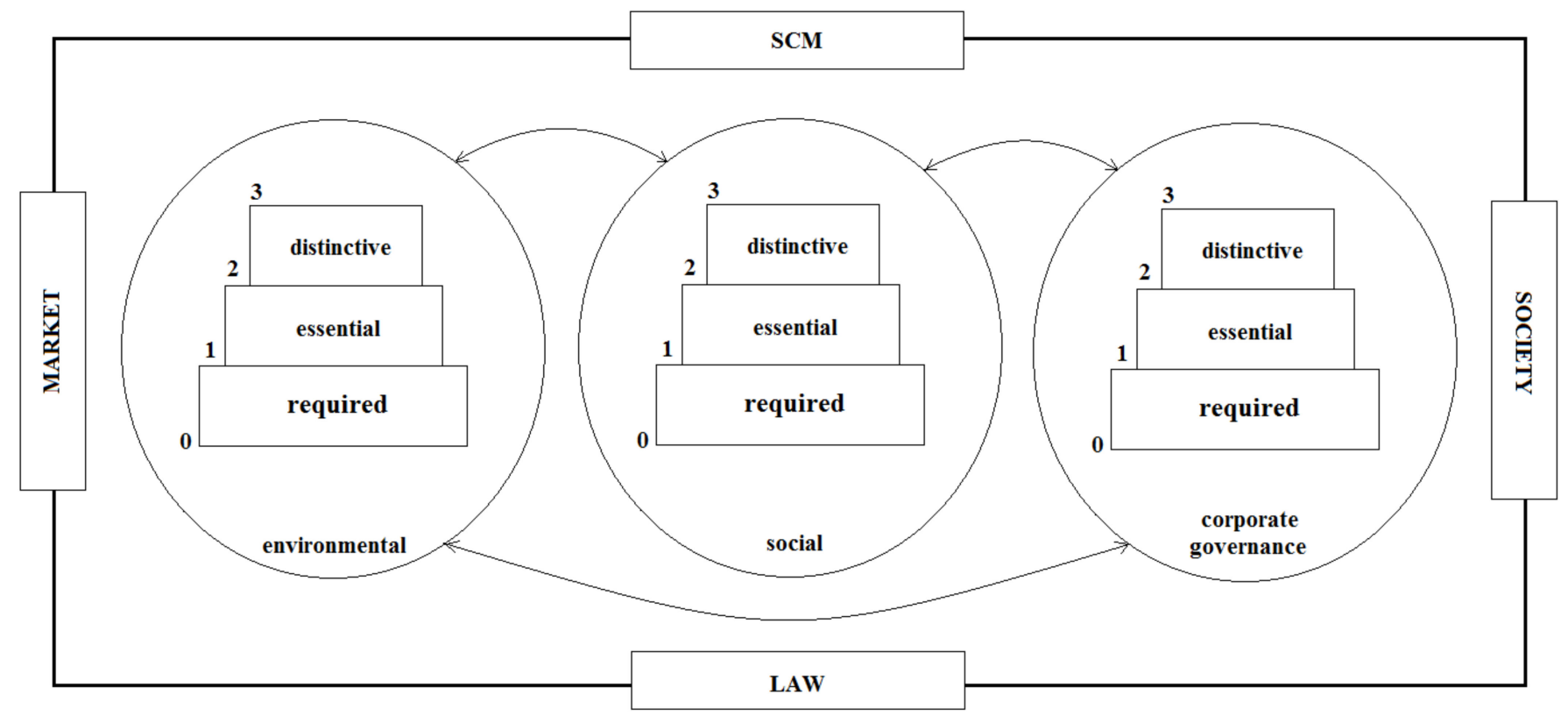

Figure 6. CSR model for companies producing and supplying energy.

There are three areas of responsibility for companies: environmental, social, and corporate governance. In each of them, a company can be characterized by three levels of responsibility: required, essential, and distinctive. This classification is based on grades used in the research. On the lowest level, companies follow only necessary rules. Higher levels of responsibility become more advantage than obligation. The second level should be the threshold met by all the enterprises. However, the research showed that companies in selected CSR areas remained at level I. The highest level should be the state to which most of the companies will aim to achieve. Unfortunately, it is a long way from being achieved by most companies. There are four external factors which regulate the scope of responsibilitymarket, law, society (including stakeholders), and supply chain management. The three indicated aspects of CSR constitute the basis of this concept. It is undoubtedly influenced by the market and economic factors that determine the company's operations. The basis for sustainable operation is the achievement by the enterprise of a stable economic situation, which is largely dependent on market factors. This, in turn, is related to politics and law. In this sector, the legal standards and ordinances of many organizations, including the European Parliament, will have a key impact on the activities of these enterprises. As presented in the theoretical part of the article, the Member States have set standards that directly apply to all members and constitute the idea behind the CSR concept. The approach and the increase in public awareness will also have a key impact on the level of implementation of the CSR concept. It is people who currently decide about the activities of enterprises and their level of development. Public relations and opinions about an enterprise decide whether to be or not to be. Supply chain management is a fairly new issue raised at all levels of management. The activities of the companies are associated with their influence on the subcontractors. In addition, it is companies that can force their supplies to run their activities in an ecological and pro-social manner. Supply chains are one of the new issues that arose in terms of assessing the level of CSR. This is undoubtedly related to the growing awareness of the responsibility for cooperation and joint action for a given goal. 


\section{Conclusions}

The research showed that all assessed companies perform significantly better in corporate governance than in environmental and social areas of CSR. This is as market stakeholders and government bodies have the greatest influence on the performance of companies. The means of their influence are law regulations and capital. The impact of the society is also important, but not so effective, as there are no such tools for influencing enterprises. The role of the supply chain on CSR has been marginalized in practice.

The companies involved in the production and supply of energy did not differ significantly from other sectors in terms of the application of the CSR concept. However, there were some differences between them at the level of individual indicators that must be taken into account when designing and implementing a CSR strategy. Sector-specific problems in energy-related groups concern forced labour and human rights in supply chain. It means that the economy-wide problem of expanding the CSR idea above the individual level is even more visible in mining, energy, and energy utilities. In most of supply chain companies, the representing mentioned groups play a role of supplier. It is crucial to track their suppliers in order to identify and solve problems concerning human rights. The characteristics of the energy-related companies' activities indicate that many of the abuses may be directed, not at independent external entities, but at indirectly employed workers.

There were also differences between energy-related companies observed. The group of energy obtained significantly lower grades than mining and energy utilities groups in environmental indicators, and lower than mining in social indicators. Finding the cause of this situation demands even more detailed approach. In the next phase of research, groups of mining, energy and energy-utilities will be divided into more specialized branches and geographic regions to find out other important differentiating factors.

Author Contributions: Conceptualization, K.H. and M.K.; methodology, K.H. and M.K.; software, K.H. and M.K.; validation, K.H. and M.K.; formal analysis, K.H. and M.K.; investigation, K.H. and M.K.; resources, K.H. and M.K.; data curation, K.H. and M.K.; writing—original draft preparation, K.H. and M.K.; writing—review and editing, K.H. and M.K.; visualization, K.H. and M.K.; supervision, K.H. and M.K.; project administration, K.H. and M.K.; funding acquisition, K.H. and M.K. All authors have read and agreed to the published version of the manuscript.

Funding: This research received no external funding.

Institutional Review Board Statement: Not applicable.

Informed Consent Statement: Not applicable.

Data Availability Statement: Not applicable.

Conflicts of Interest: The authors declare no conflict of interest.

\section{References}

1. World Commission on Environment and Development. Our Common Future; Oxford University Press: Oxford, UK, 1987; Available online: https://sustainabledevelopment.un.org/content/documents/5987our-common-future.pdf (accessed on 15 July 2021).

2. Gore, A. Earth in the Balance; Chelsea Green: New York, NY, USA, 1992.

3. Norouzi, N.; Ataei, E. Globalization and sustainable development. Int. J. Innov. Res. Humanit. 2021, 1, 69.

4. Surówka, M.; Popławski, M.; Fidlerová, H. Technical Infrastructure as an Element of Sustainable Development of Rural Regions in Małopolskie Voivodeship in Poland and Trnava Region in Slovakia. Agriculture 2021, 11, 141. [CrossRef]

5. Kelimeler, A. Constitution and Sustainable Development. İstanbul Hukuk Mecmuası 2020, 78, 1921-1957. [CrossRef]

6. United Nations. UNGC our Participants. Available online: https://www.unglobalcompact.org/what-is-gc/participants (accessed on 11 August 2020).

7. Adamczyk, J. Obszary i kryteria oceny społecznej odpowiedzialności przedsiębiorstw. Pr. Nauk. Uniw. Ekon. We Wrocławiu 2014, 338, 9-19. [CrossRef]

8. Friedman, M. The Social Responsibility of Business is to Increase Its Increase Its Profits. New York Times Magazine, 13 September 1970; 32-33.

9. Kang, Y.C.; Wood, D.J. Before Profit Social Responsibility Turning the Economic Paradigm Upside Down. Bus. Soc. 1995, 6, 809-829.

10. Grffin, R.W. Podstawy Zarzadzania Organizacjami; PWE: Warszawa, Poland, 2004. 
11. European Commission "Green Book". Available online: http://ec.europa.eu/employment_social/soc-dial/csr/greenpaper.htm (accessed on 30 July 2021).

12. Carroll, A.B. The Pyramid of Corporate Social Responsibility: Toward the Moral Management of organizational stakeholders. Bus. Horiz. 1991, 34, 39-48. [CrossRef]

13. Huk, K. Logistyka miejska a społeczna odpowiedzialność biznesu—Wspólne obszary zainteresowania. Stud. Ekon. 2015, 249, 155-163.

14. Huk, K.; Witkowski, K.; Wasilewski, W. Social aspects of urban logistics in the context of CSR. Logist. Transp. 2016, 3, 13-20.

15. Garriga, E.; Melé, D. Corporate Social Responsibility Theories: Mapping the Territory. J. Bus. Ethics 2004, 53, 51-71. [CrossRef]

16. Carroll, A.B. A Three-Dimensional Conceptual Model of Corporate Performance. Acad. Manag. Rev. 1979, 4, 497-505. [CrossRef]

17. Carroll, A.B. Busieness and Society: Ethics and Stakeholder Management; College Division South-Western Publishing Co.: Cincinaati, OH, USA, 1993.

18. Drucker, P.F. The New Meaning of Corporate Social Responsibility. Calif. Manag. Rev. 1984, 26, 53-63. [CrossRef]

19. Sokołowska, A. Społeczna odpowiedzialność małego przedsiębiorstwa-Przejawy i dylematy. E-Mentor 2009, 5, 31-37.

20. Gableta, M. W kierunku operacjonalizacji pojęcia odpowiedzialności społecznej w obszarze zatrudnienia. In Kierunki $i$ Dylematy Rozwoju Nauki i Praktyki Zarzadzania Przedsiębiorstwem; Jagoda, H., Lichtarski, J., Eds.; Wyd. UE We Wrocławiu: Wrocław, Poland, 2010; p. 73.

21. Stareček, A.; Gyurák Babel’ová, Z.; Makyšová, H.; Cagáňová, D. Sustainable Human Resource Management and Generations of Employees in Industrial Enterprises. Acta Logist. 2021, 8, 45-53. [CrossRef]

22. Adamiak, A.; Nowicki, M. Etyka i społeczna odpowiedzialność biznesu. In Podstawy Zarzadzania; Zakrzewska-Bielawska, A., Ed.; Oficyna Wolters Kluwer Business: Warszawa, Poland, 2012; p. 504.

23. Young, S. Etyczny Kapitalizm. Jak Na Powrót Połaczyć Prywatny Interes z Dobrem Publicznym; Metamorfoza: Wrocław, Poland, 2005.

24. Ackerman, R.W. How Companies Respond to Social Demands. Harv. Univ. Rev. 1973, 51, 88-98.

25. Jones, T.M. Corporate Social Responsibility Revisited Redefined. Calif. Manag. Rev. 1980, 5, 59-67. [CrossRef]

26. Vogel, D. The Study of Social Issues in Management. A Critical Appraisal. Calif. Manag. Rev. 1986, 28, 142-151. [CrossRef]

27. Wartick, S.; Mahon, S. Towards a Substantive Definition of the Corporate Issue Construct. A Review and Synthesis of Literature. Busieness Soc. 1994, 33, 293-311. [CrossRef]

28. Weber, J.; Wasielewski, D. Corporate Social Responsibility; IABS: Pittsburgh, PA, USA, 2018; p. 40.

29. Sokołowska, A. Społeczna Odpowiedzialność Małego Przedsiębiorstwa. Identyfikacja-Ocena-Kierunki Doskonalenia; Wyd. Uniwerystetu Ekonomicznego We Wrocławiu: Wrocław, Poland, 2013; p. 18.

30. Frederick, W.C. The Growing Concern over Business Responsibility. Calif. Manag. Rev. 1960, 2, 54-61. [CrossRef]

31. Quinn, A.K.; Bruce, N.; Puzzolo, E.; Dickinson, K.; Sturke, R.; Jack, D.W.; Mehta, S.; Shankar, A.; Sherr, K.; Rosenthal, J.P. An analysis of efforts to scale up clean household energy for cooking around the word. Energy Sustain. Dev. 2018, 46, 1-10. [CrossRef]

32. Olajuyin, E.A.; Areola, R.I. Energy and Sustainable development in developing countries. J. Electr. Electron. Eng. 2019, 14, 12-15.

33. Japee, G.P.; Oza, P. Redefining Sustainable Development. Psychol. Educ. 2021, 58, 5610-5619.

34. Brent, A.C. Renewable Energy for Sustainable Development. Sustainability 2021, 13, 6920. [CrossRef]

35. Saraswat, S.K.; Digalwar, A.K. Evaluation of energy alternatives for sustainable development of energy sector in India: An integrated Shannon's entropy fuzzy multi-criteria decision approach. Renew. Energy 2021, 171, 58-74. [CrossRef]

36. Schlör, H.; Fisher, W.; Hake, F. Methods of measuring sustainable development of the German energy sector. Appl. Energy 2013, 101, 172-181. [CrossRef]

37. Zha, J.; Tan, T.; Ma, S. How to reduce energy intensity to achieve sustainable development of China's transport sector? A cross-regional comparison analysis. Socio Econ. Plan. Sci. 2020, 71, 2662. [CrossRef]

38. Abdallah, K.B.; Belloumi, M.; Wolf, D. Indicators for sustainable energy development: A multivariate cointegration and causality analysis from Tunisian road transport sector. Renew. Sustain. Energy Rev. 2013, 25, 34-43. [CrossRef]

39. Islam, S.M.N. Sustainable economic developments in the australian energy sector: Findings of the australian energy planning system optimization model (AEPSOM). Renew. Sustain. Energy Rev. 1997, 1, 229-238. [CrossRef]

40. Karaman, A.S.; Orazalin, N.; Uyar, A.; Shahbaz, M. CSR achievement, reporting, and assurance in the energy sector: Does economic development matter? Energy Policy 2021, 149, 1-15. [CrossRef]

41. Shahbaz, M.; Karaman, A.; Kilic, M.; Uyar, A. Board attributes, CSR engagement, and corporate performance: What is the nexus in the energy sector? Energy Policy 2020, 143, 1-14. [CrossRef]

42. ECOTEC. The Impact on Employment in EU-25 of the Opening of Electricity and Gas Markets, and of Key EU Directives in the Field of Energy. Case Study Country Chapter-SWEDEN and Vattenfall; ECOTEC Research \& Consulting: Birmingham, UK, 2007.

43. Latin American Energy Organization (OLADE). Methodology for the Implementation of CSR Actions in Energy Companies with Gender Equality; OLADE: Quito, Ecuador, 2014.

44. Wilde-Ramsing, J. Quality Kilowatts: A Normative-Empirical Approach to the Challenge of Defining and Providing Sustainable Electricity in Developing Countries. 2009. Available online: https://www.somo.nl/wp-content/uploads/2009/06/QualityKilowatts.pdf (accessed on 9 September 2021).

45. Nuorkivi, A.; Killström, N.; Saarnia, P.; Tähti, E.; Markovitch, J.; Naumov, G.; Hamacher, T. Energy. Future. Responsibility. Promoting Energy Saving and Corporate Social Responsibility in the Baltic Sea Region; Uusimaa Regional Council: Helsinki, Finland, 2007.

46. Stjepcevic, J.; Siksnelyte, I. Corporate Social Responsibility in Energy Sector. Transform. Bus. Econ. 2017, 16, 21-33. 
47. Jenkins, H. Corporate Social Responsibility and the Mining Industry: Conflicts and Constructs. Corp. Soc. Responsib. Environ. Manag. 2004, 11, 23-34. [CrossRef]

48. Jenkins, H.; Yakovleva, N. Corporate social responsibility in the mining industry: Exploring trends in social and environmental disclosure. J. Clean. Prod. 2006, 14, 271-284. [CrossRef]

49. Oxfam International. Corporate Social Responsibility in the Mining Sector in Peru; Oxfam International: Nairobi, Kenya, 2006.

50. Vintró, C.; Comajuncosa, J. Corporate Social Responsibility in the Mining Industry: Criteria and Indicators. Dyna 2010, 77, 31-41.

51. Yakovleva, N.; Vazquez-Brust, D.; Mutti, D. Corporate Social Responsibility of Mining Companies in Argentina. Clim. Chang. Green Growth 2010, 55, 1-12.

52. Gurská, S.; Válová, A. Corporate Social Responsibility in Mining Industry. Acta Univ. Agric. Silvic. Mendel. Brun. LXI 2013, 61, 2163-2170. [CrossRef]

53. Sarkar, A.N. Review of Strategic Policy Framework for Re-Evaluating 'CSR' Programme Impacts on the Mining-Affected Areas in India. Adv. Sustain. Environ. Justice 2013, 11, 217-261.

54. Ofori, D.F.; Ofori, A.T. Mining Sector CSR Behavior: A Developing Country Perspective. Afr. J. Manag. Res. 2014, $22,62-84$.

55. Pactwa, K.; Woźniak, J. Knowledge of CSR issues among mining business stakeholders and the academic environment-Case study from Poland. Gospod. Surowcami Miner. Miner. Resour. Manag. 2020, 36, 149-166.

56. Fact Sheets on the European Union. Available online: https://www.europarl.europa.eu/factsheets/pl/sheet/68/politykaenergetyczna-zasady-ogolne (accessed on 21 November 2021).

57. MSCI. Global Industry Classification Standard (GICS) Methodology; MSCI: New York, NY, USA, 2020; pp. 6-9.

58. Razali, N.M.; Yap, B.W. Power Comparisons of Shapiro-Wilk, Kolmogorov-Smirnov, Lilliefors and Anderson-Darling Tests. J. Stat. Modeling Anal. 2011, 2, 21-33.

59. Guo, S.; Zhong, S.; Zhang, A. Privacy-preserving Kruskal-Wallis test. Comput. Methods Programs Biomed. 2013, 112, 135-145. [CrossRef]

60. Ostertagová, E.; Ostertag, O.; Kováč, J. Methodology and Application of the Kruskal-Wallis Test. Appl. Mech. Mater. 2014, 611, 115-120. [CrossRef]

61. Zar, J.H. Biostatistical Analysis; Prentice Hall: New Jersey, NJ, USA, 1998.

62. Warner, R.M. Applied Statistics; SAGE Publications: Thousand Oaks, CA, USA, 2008.

63. Kurowski, M. Selected Environmental Aspects in the Context of the Concept of CSR in Logistics Companies. Econ. Environ. Stud. 2017, 17, 1003-1016. [CrossRef]

64. Lebaron, G. The Role of Supply Chains in the Global Business of Forced Labour. J. Supply Chain. Manag. 2021, 57, 1-14. [CrossRef] 